\title{
Mineral Deposits Safeguarding and Land Use Planning-The Importance of Creating Shared Value
}

\author{
Linda Wårell
}

Citation: Wårell, L. Mineral Deposits Safeguarding and Land Use Planning-The Importance of Creating Shared Value. Resources 2021, 10, 33. https://doi.org/10.3390/ resources 10040033

Academic Editor: Krzysztof Galos

Received: 8 March 2021

Accepted: 8 April 2021

Published: 12 April 2021

Publisher's Note: MDPI stays neutral with regard to jurisdictional claims in published maps and institutional affiliations.

Copyright: (C) 2021 by the author. Licensee MDPI, Basel, Switzerland. This article is an open access article distributed under the terms and conditions of the Creative Commons Attribution (CC BY) license (https:// creativecommons.org/licenses/by/ $4.0 /)$.
Department of Business Administration, Technology and Social Sciences, Luleå University of Technology, 97187 Luleå, Sweden; linda.warell@ltu.se

\begin{abstract}
During the last few decades many European countries have developed policies directed towards mineral deposit safeguarding. However, as other land uses often are in conflict with mineral deposit safeguarding, the implementation of these policies is many times more difficult in practice. The aim of this paper is to investigate the link between land use planning and mineral resources, when using a shared value perspective. The analysis is focused on the mineral-rich Nordic countriesSweden, Norway and Finland-and a number of mining projects are analyzed. The analysis rests in Porter and Kramer's arguments for the importance of creating shared values. The results indicate that a shared value perspective has been present in the analyzed case studies, as many of the key ways for creating shared value are identified in the projects. This illustrates the importance of linking social value to economic value in mining projects, even if this is not clearly stated in the relevant legislation. As it is often the unpredictability of the regulatory framework that hinders mineral extraction, it is suggested that Social Impact Assessments (or similar) are formalized in the regulatory framework to ensure that social value is linked more clearly to the land use process related to access to minerals.
\end{abstract}

Keywords: mineral deposits; safeguarding; land use planning; creating shared value; dialogues; permitting process

\section{Introduction}

An expanding global population and an increasing demand for many metals and minerals highlights the importance of a sustainable supply of raw materials. For example, the Horizon 2020 Programme on Raw Materials from the EU stresses the importance of ensuring the access to domestic sources of mineral raw materials [1], which is also addressed in the EU Action Plan on Critical Raw Materials [2]. It is thus argued that the growth and competitiveness of European industry requires a sustainable extractive activity in Europe, so that the EU industry does not depend entirely on imports from foreign sources. Furthermore, an increased focus on a transition to a low-carbon future will require an increased amount of minerals and metals in the future, e.g., [2-4]. Yet, several competing land uses, such as urban sprawl, infrastructure development and nature conservation decreases the available land areas for exploration and exploitation of mineral deposits. In other words, as the supply of mineral raw materials to the European industry from domestic sources is identified as important, there is a need to safeguard the access to deposits of mineral resources in Europe.

Many European countries have, during the last decades, developed policies directed towards mineral deposit safeguarding, e.g., [5-8]. However, as other land uses often are in conflict with mineral deposit safeguarding, the implementation of these policies are many times more difficult. Land use planning, often in the hands of regional and local authorities, are therefore a task identified as especially important for successful mineral deposit safeguarding to ensure future mining investments [9]. In relation to large investments in mining projects, relevant regional authorities are thus faced with major challenges regarding, e.g., infrastructure, supply of skills, housing and balances between different interests of the involved actors [10]. The regional authorities need to have a 
long-term perspective in its land use planning process, to ensure safeguarding of mineral deposits, and at the same time balance other needs and interests. This can be seen as an almost impossible task. However, this is addressed by Porter and Kramer in their notion of "Creating Shared Value" [11]. Their main argument is that the competitiveness of companies, and the health of the surrounding community, are mutually dependent. They stress that societal needs (not only economic needs) define markets, and more specifically, that social harm creates an internal cost for firms. The authors present three key ways to create shared values for societal and economic progress; by reconceiving products and markets, redefining productivity in the value chain, and building supportive industry clusters at the company's locations [11]. The concept of creating shared value can be applied to any industry, but it is highly relevant for the mining industry as mineral resources are often extracted in areas where there are many competing land uses, and thus possible societal harm. We are therefore interested in finding out to what extent previous mining projects that have addressed the issue of competing land uses, have created a shared value in that process.

The aim of this paper is to investigate the link between mineral deposit safeguarding and land use planning, using a shared value perspective. The analysis focuses on five mining projects in Nordic countries (Sweden, Norway and Finland) that are defined as "Good practice" cases, in the EU project Minland, related to linking land use planning and mineral safeguarding issues. These three Nordic countries have important mineral resources and at the same time have well-developed mineral regulations, where land use planning often is linked to the procedure. However, all three nations also share Sami populations and thus need to consider their land use interests in most mining operations (as the major mineral resources are located in reindeer herding areas). It is thus of interest to analyze if a shared value perspective [11] has been applied in the cases that previously have been identified as "Good practice" regarding linking land use planning and mineral safeguarding.

Previous research on issues related to the implementation of mining operations shows that land-use conflicts are difficult to solve as they often are based on fundamental different ideas about human-nature relationships and its relevance for sustainable development [12]. Important for this issue is an understanding of socioeconomic value creation in mining operations, as well as how to increase local participation in the planning for mining operations [13]. Another issue that previous research stresses as important for the successful implementation of mining operations is benefit sharing, e.g., [14,15], and the regional economic impact of mining, e.g., [16,17].

Considering this, it is highly important that the authorities that are responsible for the land use planning are well-informed of how to avoid conflicts in the case of a potential mining operation. However, there are few academic studies available reporting the authorities' role in linking mineral deposit safeguarding to the land use planning process. Gugerell et al. in 2020 analyzed the role of minerals safeguarding in land-use planning policy on a regional level in Austria [7]. It is highlighted that land use planning instruments available for regional authorities, and coordination and communication in the policy process, is important for an efficient process. Mateus et al. in 2017 developed a multi-dimensional methodology to delimit areas in order to safeguard future access to mineral resources [18]. The methodology considers a level of geological knowledge, along with economic, environmental and social development and acceptance dimensions. In a report performed by the Swedish Agency for Economic and Regional Growth, based on interviews of local and regional authorities, it is found that the following areas are particularly important to take into account in the land use planning process related to mineral deposits: sustainable business development; reindeer husbandry; the nature and environmental protection perspective; the tourism industry; and the local population [10]. However, even though these to some extent touch on the issue of value creation, this is not specifically addressed as an important component for the successful implementation 
of mining projects. This paper thus adds to previous research by adding a shared value perspective to a number of mining projects in Sweden, Norway and Finland.

The paper proceeds with a section that provides an overview of relevant mining regulation in Sweden, Norway and Finland. An understanding of the legal context for the studied mining projects is important for the later analyses. In the following section the methodological approach to analyze the link between mineral deposit safeguarding and land use planning is presented. The focus here is mainly on the concept of Creating Shared Value according to Porter and Kramer [11]. In Section 4 the mining project cases are presented, and analyzed using a shared value perspective. In the following sections the results from the case studies are discussed, and finally some concluding remarks are made.

\section{Mining Regulation in Sweden, Norway and Finland}

This section presents relevant mining regulation in Sweden, Norway and Finland to better understand the legal context that mining operations need to consider in order to start a project in these countries. The section ends with a comparison and a discussion of issues related to mining regulations, and specifically in relation to other land use interests, in the three countries.

\subsection{Mining Regulation in Sweden}

Sweden has a relatively large mining sector from a European perspective, considering that it was the largest producer of iron ore, led and zinc, and the second largest producer of silver, the third largest producer of gold, and the fourth largest producer of copper in 2019 [19]. In 2013 the Swedish government presented a Mineral Strategy, with the aim to "increase the competitiveness of the Swedish mining and minerals industry so that Sweden maintains and strengthens its position as the EU's leading mining nation" [20]. The strategy was a pro-mining statement, with the aim of attracting investments and significantly increasing the Swedish mining sector. This strategy had a strong market liberal approach, which did meet quite a lot of local critique [21]. However, since then, the Swedish government has changed, and Sweden has fallen considerably in the Fraser Institutes ranking regarding attractive mining investment nations. Regarding investment attractiveness Sweden has fallen from position 8 in 2016 to 36 in 2020, and regarding policy perception index Sweden's position has moved from 3 to 20 in the same years [22].

Swedish legislation relevant for access to mineral resources is divided in two main legislations; the Minerals Act and the Environmental Code. The Minerals Act (1991:45) covers the permitting and concessions necessary for exploration and exploitation of mineral resources. The exploration permit gives an exclusive right to explore an area and its potential mineral deposit, and this is applied from the Mining Inspectorate of Sweden. If an exploration permit is granted the operator needs to prepare a detailed work plan for the exploration work, and agree with landowners and other stakeholders (for example the County Administrative Board, the municipality and affected Sami villages) about this work plan. Before conducting any investigations, the operator must ensure that it can compensate land and property owners for any damage or encroachment [23].

If the operator has found a promising mineral deposit, they can go ahead and apply for an exploitation concession with the Mining Inspectorate of Sweden. Before this application is written, it is appropriate that the operator calls for consultation with the municipality, the County Administrative Board and the local and regional stakeholders (e.g., local residents, local associations, Sami villages and the tourism industry). At this stage, the Mining Inspectorate will investigate the applicant's financial situation in order to evaluate the company's financial possibility for utilizing a deposit. An assessment is done even if the mining is in conflict with the provisions in the Environmental Code (Chapters 3 and 4). The Mining Inspectorate then decides whether an exploitation concession shall be granted. After this the County Administrative Board, which is the referring authority, can either approve or reject the decision. The municipality can be involved in the process in the consultations that the operator needs to have before the finalizing of their Environmental 
Impact Assessment (EIA). Furthermore, in the assessment regarding whether mining is in conflict with the Environmental Code, the municipality is asked to express their view regarding potential conflicts to other national interests in land use planning.

The Environmental Code is the legislation that links mineral resources to land use planning and where environmental concern is taken on a national level. It is also here that the "areas of national interest" are defined. There is a total of 11 areas of national interest in Sweden, of which mineral deposits is one (number 6). The areas of national interests in Sweden are; 1. Reindeer husbandry, 2. Commercial fishing, 3. Nature conservation, 4 . Outdoor recreation, 5. Conservation of the cultural environment, 6 . Deposits of substances or materials, 7. Industrial production, 8. Production and distribution of energy, 9. Final disposal of nuclear waste, 10. Infrastructure and communication, 11. Waste treatment (Environmental Code, Ch. 3). It is common that these areas overlap, for instance that defined areas of mineral deposits are overlapped by areas defined as important for reindeer herding and nature conservation. In such cases, it is advised that a balance of interests should be made and that presence is to be given to the best sustainable use of the land (including environmental, social and economic sustainability) [24].

Another piece of legislation that is important in relation to mineral resources and land use planning is the Planning and Building Act. This Act works in parallel with the Minerals Act, and its main purpose is to regulate the land use in order to reduce the impact on the environment as well as to reduce transaction costs due to industrial land uses. In the Planning and Building Act it is noted that the land use planning is primarily a municipal concern [25].

\subsection{Mining Regulation in Norway}

The mining industry (for metals and industrial minerals) in Norway is notably smaller than its Swedish and Finnish counterparts, but it is an industry that has been growing more recently. Similar to Finland and Sweden, Norway has formulated a strategy for the minerals industry, adopted in 2013. In this it is stated that the main aim with the strategy is that "growth in the industry shall be strengthened by means of a continued commitment to mapping of mineral deposits, access to information about mineral resources in Norway, better resource planning, a continued development of the mineral agencies and access to knowledge and a competent workforce" [26]. Regarding the Fraser Institute ranking for investment attractiveness, Norway receives a considerably less favorable ranking with regards to investment attractiveness compared to Finland and Sweden. In 2020 it ranked 54 out of 77 jurisdictions, down from 37 out of 104 jurisdictions in 2016. Regarding the index related to mining policies, Norway is rated slightly higher, considering its rank of 27 of the 77 jurisdictions that were included in the survey in 2020 [22].

The main regulations related to the safeguarding of minerals in Norway is the Minerals Act, which was adopted in 2009. The Minerals Act is thus a more recent phenomenon compared to its Swedish counterpart. The objective according to the Norwegian Government was to "promote and ensure socially responsible administration and use of mineral resources in accordance with the principle of sustainable development" [27]. The Minerals Act covers all prospecting and exploitation of minerals, and differentiates between stateowned minerals and land-owned minerals. Compared to Sweden and Finland, there are more minerals that are owned by landowners vis-à-vis state-owned minerals. It is also the case that the archipelago of Svalbard is not covered by this legislation, and special provisions apply to the Finnmark County [28].

Exploration of landowner minerals requires an agreement between the landowner and the explorer. If an agreement cannot be reached an application can be sent to the Directorate of Mining to acquire the rights needed to explore. The landowner, the land user, the county governor, the county municipality and the municipality will have an opportunity to comment before a permit is granted. In the case of a state-owned mineral, an exploration permit shall always be applied from the Directorate. The rights and limitations for the permits are dictated in the Minerals Act, and regulations are covered by the Ministry of 
Trade and Industry. Furthermore, in Norway, a permit necessitates that a detailed work plan is provided and agreed upon [28].

For an extraction permit regarding state-owned minerals, the applicant's finances will be scrutinized to ensure economic feasibility to extract the mineral. An extraction permit will also have to be supplemented with a plans of operations, and if the extraction is above 10,000 cubic meters, an operation license is required. This license is also granted by the Directorate of Mining, and should include a work plan, an assessment of security, and a plan of financing and investments. This should be in accordance with the regulation in the municipal master plan, and also related to the local development plans, and linked to the Planning and Building Act [29].

In Norway, the Sami population is by far the largest compared to both Sweden and Finland, and the Samis exercise an exclusive right to reindeer herding (as in Sweden). Unlike both Sweden and Finland, Norway ratified the ILO 169 Convention in 1990, which has been implemented in Norwegian law and in the specified Finnmark Act that was adopted in 2005. A consequence of the Finnmark Act was that $95 \%$ of land that were previously state-owned has now been transferred to the established Finnmark Estate, which consists of board members both from the Norwegian Sami Parliament and the local County council. It should further be noted that it is stated that the Minerals Act should be applied in accordance with international rules regarding indigenous people, i.e., the Samis. Special provisions apply to the Finnmark area, to take the Sami population into account. It should also be noted that the Sami Parliament did not support the adoption of the Minerals Act in 2009 [28].

Another important piece of legislation regarding mineral resources and land use planning in Norway is the Planning and Building Act, adopted in 2008. In Norway, the municipality is responsible for local land use planning and it is therefore responsible for the final decision regarding whether mineral extraction should be allowed. It is therefore important that the mining operators apply to the municipality for regulating the area for mining activities. Furthermore, the main Environmental Impact Assessment in Norway is generally conducted as part of the municipal planning process. In this, a hearing with relevant stakeholder is an important part.

Other relevant environmental legislation for mining operations includes the Nature Diversity Act and the Pollution Control Act, where the former relates to principles such as the polluter pays, the precautionary principle and the best available technique. The Pollution Control Act is directed towards emissions, e.g., noise, dust, chemicals, greenhouse gases and other hazardous emissions. For the extraction of minerals, permits need to be granted by the Norwegian Environment Agency, and when there are significant amount of emissions an EIA according to the Act is necessary. Mining waste is also regulated, which is covered by the Mining Waste Directive [28].

\subsection{Mining Regulation in Finland}

Compared to Sweden and Norway, the Finnish mining industry is more dominated by foreign-owned companies, and it is ranked significantly higher on the Fraser Institutes list regarding attractive mining investment countries compared to Sweden and Norway. In 2020 it was ranked as 10 out of 77 jurisdictions regarding investment attractiveness, and as the third best jurisdiction related to mining policy [22]. Finland was also the first of the three countries to formulate a strategy for the minerals industry, adopted in 2010. In this it is stated that the main aim with this strategy was to improve conditions and competitiveness of the industry, focusing on securing a supply of raw materials, strengthening the minerals policy, reducing environmental impact and increasing its productivity and technological development [30].

The main regulation in Finland related to mineral resources is the Mining Act that was issued in 2011, and a new Government Decree related to mining activities that was established one year later. The main purpose of these new regulations was to include environmental and social considerations in the mining permitting process. The legislation 
clarifies the responsibilities of exploration and mining operators towards other stakeholders and provides possibilities for landowners, local authorities and citizens to provide their views about the project. The Mining Act states that its main objective is to promote mining and manage the land use of mining operations in a sustainable way, including social, economic and environmental perspectives. The Act covers metallic minerals, but not industrial minerals which are regulated in the Land Extraction Act (which will not be addressed here), and gold and some gemstones require special provisions [31]. The socalled mining minerals in Finland are similar to the Norwegian state-owned minerals and the Swedish concession minerals.

Regarding exploration, Finland allows everyone to make geological measurements, observations and minor samples, even on land owned by others, provided that no damage is inflicted. There are certain limitations to this, and a notification that includes a plan if sampling is to be made has to be sent to the landowner. A more extensive exploration requires a permit from the Finnish Safety and Chemicals Agency (Tukes), as well as if the landowner does not consent to minor exploration. What an application for an exploration permit should include is stated in Section 34 in the Mining Act, e.g., information on the area, other relevant land uses, preliminary assessment of the mining minerals, a work plan, an assessment of environmental and other impacts, as well as a waste management plan and plan of mine closure [31].

If exploration is successful, a mining permit is required in order to establish a mine. The license is also provided by the Tukes, except if the mining is of uranium and thorium (when the Government decides). This permit should include similar information as the exploration permit, but a more extensive assessment of the feasibility of the mineral deposit for exploitation is required, including measures to protect health, safety and the environment. Furthermore, a mining permit should include an EIA, which is specified in the Act on Environmental Impact Assessment Procedure. Statements regarding the mining operations should also be given by the relevant municipality, the regional Centre of Economic Development, Transport and Environment, and the authority responsible for land use planning of the area. It is required that a hearing is arranged where important stakeholders can express their opinions, as well as providing answers to important issues [28].

Regarding access to land, it is stated that it should be arranged by voluntary arrangements. However, if this cannot be achieved a permit can be granted by the government (if the mining project is of importance to public needs). Importance of public needs relates to the local and regional economy and employment, but also to the societal need for a raw material supply. Before a permit is granted, the relevant municipality, regional council and Centre of Economic Development, Transport and Environment are requested to provide a statement regarding the specified area. An additional permit needed is the Mining safety permit, which focus on the mining safety requirements regarding the mining operation. Here, relevant stakeholders are also provided with an opportunity to express their opinions [28].

The Mining Act also has the aim of securing the rights of the Sami as an indigenous population. The Sami population (including Skolt people, who have a specific Skolt Act) in Finland is significantly smaller compared to the Sami populations in Norway and Sweden. The Finnish Mining Act includes several provisions for mining activities in Sami and Skolt native areas, or in reindeer herding areas (which can differ to the native areas). This differs to the Swedish legislation, where reindeer herding is not regulated in the Minerals Act but in other legislations. Section 38 in the Finnish Mining Act specifies the exploration and mining procedure regarding applications in the Sami native land, or reindeer herding areas. The Samis' rights to maintain and develop their culture and their own language needs to be addressed before the Tukes approves any exploration or mining permits. The Sami Parliament, local reindeer owners' association and local administrations should be consulted in these questions. The Mining Act thus stresses an increased right of Sami people to influence planning and decision-making on the management and land use of state-owned land in their native area. 
Other relevant legislation related to mining in Finland is the Environmental Protection Act, which regulates emissions and environmental permits. The Water Act regulates water resource management permits, which have to be applied from the Regional State Administrative Agency. Moreover, building permits need to be applied from the municipality. In this regard, the Land Use and Building Act is of relevance. Other laws of relevance are the Nature Conservation Act, the Act of Protection of Wilderness Reserves and the Occupational Safety and Health Act [28].

\subsection{Comparison of Mining Regulation in Sweden, Norway and Finland}

The regulation related to mining is relatively similar in Sweden, Norway and Finland. However, there are some differences that are worth noting. Even though all countries in different ways recognize the rights of the Sami and reindeer herding, it is only Norway that has ratified the ILO 169 Convention regarding the rights of indigenous people. This is an important issue for the Sami populations of both Sweden and Finland, where this question is still investigated.

In comparison to Sweden and Norway, the Finnish Mining Act is more detailed, and includes more instances of mandatory public hearings. Thus, it is specified in the Mining Act that hearings and consultations should serve as a tool for solving issues related to land use. In none of the three countries is a Social Impact Assessment mandatory by law; however, they seem to be more common in Finnish mining projects compared to other countries. This is likely explained by the fact that the Finnish mining sector has more international investors compared to the Swedish and Norwegian mining sectors (and Social Impact Assessments are more common in other mining countries e.g., Canada).

In sum, we note that the permitting process in Sweden, Norway and Finland is well regulated, i.e., there are relatively clear instructions for different actors and both consultations and environmental assessments enter the process in several ways. However, despite this, there are still many unsolved issues related to mineral deposit safeguarding and land uses in the countries. For example, there have been complaints that the permitting process in Sweden is too inefficient, e.g., [32]. It is noted that no green field project has been granted a full permit since 2010, and it can take up to 15 years in Sweden to start a mining operation, and most of this time is spent waiting for a decision from the involved Swedish authorities. It is argued that the unpredictable permitting process hinders investments in the Swedish mining industry. The Swedish Government has recently started an inquiry that will review the current permitting process to achieve a more effective environmental assessment [33].

However, others also criticize the permitting process, but for opposing reasons, complaining that the permitting process has failed to take all relevant interests into account and that there is a regulatory gap between Sami rights and the permitting process, e.g., [34,35]. This highlights the inherent difficulty regarding the issue of balancing the needs of conflicting land use interests related to mineral deposit safeguarding. In [36], the impact of environmental regulations on mining competitiveness in Sweden, Finland and Russia is addressed. It is found that a lack of timeliness and predictability in the permitting process has been a significant hindering to new and expanding mining operations in the studied countries. It is stressed that both the uncertainties related to the time it takes to get a permit, as well as the nature of the conditions of the permit, is a problem in Sweden.

The following section will focus on the methodological approach to analyze the link between mineral deposit safeguarding and land use planning in a number of mining projects in Sweden, Norway and Finland.

\section{Methodological Approach}

The analysis presented in this paper is based on a literature review where a number of case studies of mining projects in the three Nordic countries-Sweden, Norway and Finland-will be analyzed in order to understand the link between land use planning and mineral safeguarding. These case studies have been prepared in the EU project Minland [9]. 
There are in total five case studies that will be analyzed: three Swedish mining projects, one Norwegian and one Finnish case. All of these case studies highlight different aspects that were so-called "Good practice" cases regarding how exploration and extraction of mineral raw materials are integrated in land use planning and practices.

In order to analyze these projects, Porter and Kramer's ideas about how to create a shared value will be applied. Their arguments are that societal needs define markets, and that social harms will create costs for companies. In a shared value perspective, there is a focus on strengthening the local cluster of supporting suppliers and other actors/institutions, to increase efficiency, quality and sustainability. The authors' definition of shared value is as follows:

"The concept of shared value can be defined as policies and operating practices that enhance the competitiveness of a company while simultaneously advancing the economic and social conditions in the communities in which it operates. Shared value creation focuses on identifying and expanding the connections between societal and economic process." ([11], p. 67)

According to Porter and Kramer, there are three key ways to create shared values for societal and economic progress: (1) by reconceiving products and markets; (2) redefining productivity in the value chain; and (3) building supportive industry clusters at the company's locations.

Regarding the first point, i.e., to reconceive products and markets, it is stressed that it is important that operating companies identify societal needs, benefits and harms that are relevant for the firms' product. In the context of mining, this implies that the mining operators should stress the importance of minerals for environmental and societal development. Here, mining companies need to continue to explore societal needs as these can change over time, and also be able to communicate that if we want to continue our transition to a carbon-neutral future, there is an increased need for minerals and metals [4]. Regarding this first point, it is also important that mining operators stress that if these minerals are not extracted in Europe, they will be extracted elsewhere, where it is highly likely that environmental regulation is less sharp. Thus, mining operators should focus on making sure their products create societal benefits, as inputs in environmentally friendly products, while at the same time not neglecting the societal harm that the extraction of the mineral can cause.

When it comes to the second point, i.e., to redefine productivity in the value chain, it is stressed that company value chains affect a number of societal issues: natural resource and water use, working conditions, health and safety, and equality in the workplace. The link to create shared value is that firms need to recognize that these issues, if not handled properly, can create costs for the companies. In economic terms, these issues give rise to so-called externalities that the firms need to consider in their operations [37]. Firms should therefore approach these societal issues with a shared value perspective, and more importantly, they should recognize that minimizing these societal issues will lead to net cost savings. Porter and Kramer stress that firms cannot only follow the regulations, they have also to be pro-active and must do what is best from a societal perspective. For mining firms, this point is crucial, as their business is dependent on natural resource use. Here it is suggested that the mining operation reflects thoroughly on how they can extract the minerals in the most resource-efficient way from a societal perspective (not only from a financial perspective). Furthermore, to create working conditions that are safe is also of utmost importance. The current industrial digitalization development is creating safer environments for many mine workers, which mining operators need to reflect upon.

The third point, i.e., enabling local cluster development, stresses that the success of every firm is dependent upon the supporting companies and the infrastructure that surrounds it. Thus, geographical concentration of firms, institutions, and the surrounding community facilitates the operation of firms. It is noted that poorly developed clusters will create internal costs for companies. Thus, companies will create shared value by building clusters that improve the companies' productivity, and addresses important issues for the 
firms' future development. When building clusters in its key locations, the firms' success will be more strongly linked to the surrounding communities' success by a multiplier effect. For mining companies, it is thus suggested that they use local suppliers and invest in local workforce development initiatives. This will create a stronger link between the company and the society that it is located in. It is also suggested that companies, in order to support cluster development, should focus on identifying gaps in their communities regarding logistics, suppliers, distribution channels, competence, educational institutions and surrounding markets. They should then focus on the weakness that imposes the largest obstacle to continued growth and productivity. Furthermore, to achieve a successful cluster development, collaboration with other important local actors is important; e.g., the private sector, government agencies, trade associations and NGOs.

In sum, creating shared value rests on firms following regulations and ethical standards, but it is suggested that companies move beyond these. It is about creating economic value through creating societal value, and companies need to recognize that their prosperity will be tightly linked to the entire communities' prosperity. The main difference between creating shared value (CSV) and corporate social responsibility (CSR) is according to Porter and Kramer, that CSV is more an integral part of a company's profitability, as it stresses that it is necessary to create social value in order to achieve economic value [11].

For the purpose of the present paper, it is also relevant to understand the role of governmental authorities in creating shared value. Porter and Kramer note that it is important that authorities at every level (national, regional and local) adopt a value approach, i.e., consider benefits and costs in all their decisions. They stress that activists often approach social improvement from an ideological perspective, as if these should be pursued at any cost, and governments often assume that there has to be a trade-off between social and economic benefits. A shared value perspective cuts across this traditional division of responsibilities of firms, authorities and the civil society [11]. The focus should be on a collaboration between these actors to create shared value for all involved parties. Related to the issue of mineral safeguarding and land use planning it should be clear that a shared values perspective implies that all affected parties of mineral operations need to be the focus of regional and local authorities. Thus, how can they foster a development where entire communities prosper due to mining operations?

Before the analysis it is also of interest to present some of the critiques that have been directed towards the concept of creating shared value. For example, shortly after [11] was published, an article in the Economist [38] argued that the ideas were "under-cooked" and thus that the shared value concept presented by Porter and Kramer is not very new. Regarding academic critique, Crane et al. argue that creating the shared value concept suffers from shortcomings, and more specifically that it is naïve about business compliance and seems to have a shallow understanding about the corporation's role in society [39]. Others have also criticized the concept, and especially that Porter and Kramer have an outdated view of Corporate Social Responsibility and are stuck in a neo-classical view of the relationship between firms and society, e.g., [40,41]. However, despite this critique, the concept of creating shared value and its fundamental ideas about economic and social value can still be applied to analyze mining projects in order to see how well these thoughts are used in the "Good practice" regarding mineral safeguarding and land use planning.

\section{Mineral Project Case Studies}

In this section, the analyses of the five case studies of mining projects will be presented. All these cases present different aspects of "Good practice" related to land use planning and mineral safeguarding. A more detailed description of these cases can be found in [9]; here the focus will be on analyzing these in terms of how well these projects adhere to a shared value perspective [11]. The cases are all located in the Northern parts of Sweden, Norway and Finland. Figure 1 presents an overview of where the cases are located. There are three cases in Sweden, where one is in the very north of the country (in the Kiruna area) and two cases in the Skellefteå area. The Norwegian case is in the Nordland County (Fylke in 
Norwegian), which borders to the two counties in Sweden (Norrbotten and Västerbotten) where the Swedish cases are located. In Finland, the case is the Kevitsa mine in Lapland, which also borders to the Swedish county Norrbotten. All of these cases are thus located geographically close in an area rich in mineral resources, but this area is also where the Sami population traditionally uses the land for reindeer herding. Below, the cases will be presented in order of country of residence.

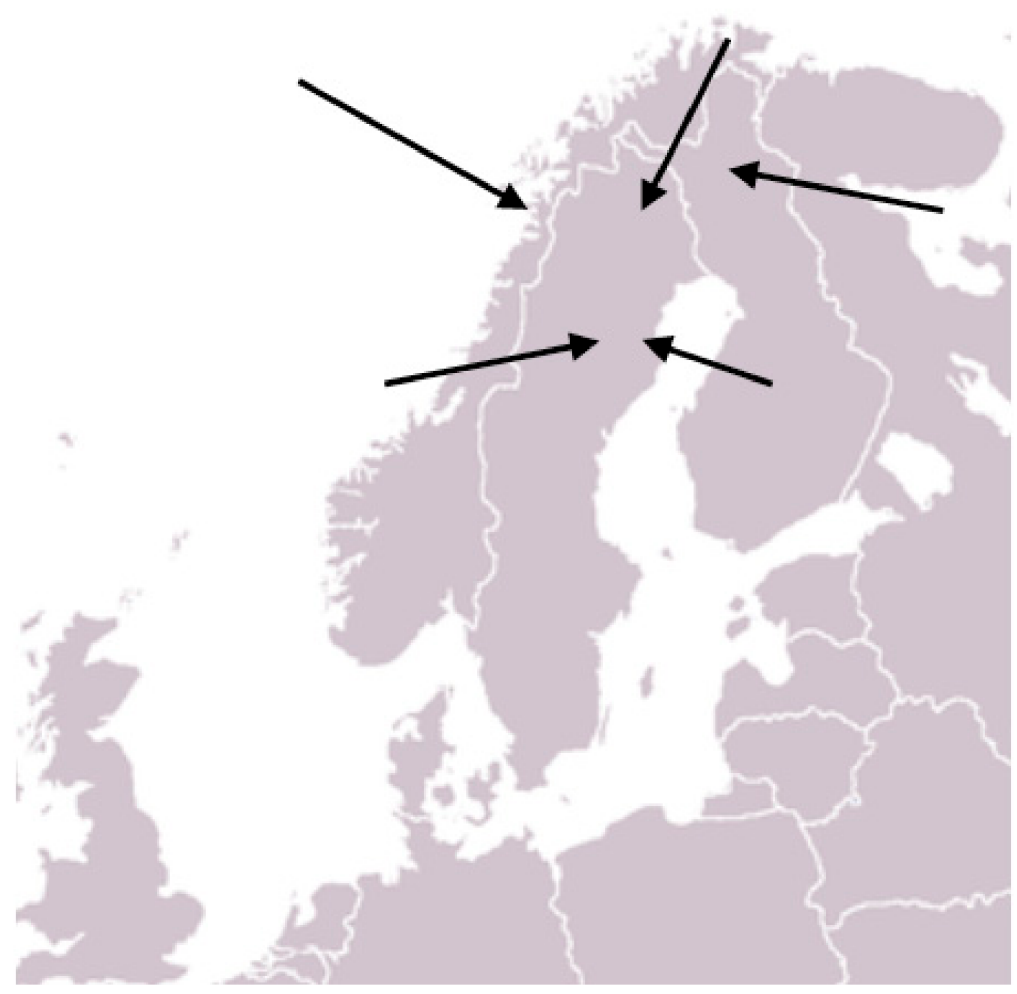

Figure 1. An overview of the geographic location of the included case studies.

\subsection{Swedish Cases}

There are three mining projects in Sweden that were regarded as "Good practice" cases regarding linking land use planning and mineral safeguarding. The first case is a gold project in Fäbodtjärn, the second a mining project in the Boliden area, and the third an Iron ore project in Mertainen, Kiruna.

\subsubsection{Gold Project in Fäbodtjärn}

This case is plans of an underground gold mine in Fäbodtjärn, located in the Skellefteå area (see Figure 1), where there are currently 5 active mines. The company that is responsible for this mining project is Botnia Exploration $A B$, who received a mining concession from the Mining Inspectorate and in December 2020 they were granted the environmental permits that are necessary for starting the operation from the Land and Environmental Court. However, this is currently appealed by the local Swedish Society for Nature Conservation division in Lycksele (a final decision on this case is expected soon). The project is an example of a small scale mine, and it is located in an area where acceptance for mining is relatively high. It does, however, affect other national interests. These include one major river (nature conservation area) and it is located within an area where reindeers are herded (reindeer husbandry).

In the Minland project, this case is noted as a "Good practice" case in linking land use planning and mineral safeguarding for a number of reasons [42]. The first aspect is that the project has been successful in linking mining and land use policy. It is here noted that 
all parts of the permitting and relevant land use policies are clearly connected, and linked to the overall system of national interests in Sweden. The second aspect notes that the geological information available in this case have been of a high quality, which has been made available to the industry. Furthermore, the geological data have also been used for land use planning. The third aspect is that this case has involved local stakeholders at an early phase. The fourth aspect is related to test mining and similar to the second aspect, this part highlights that geological information and data have been archived and shared with relevant actors both for test purposes but also for land use planning and denoting the area as being of national interest. The fifth aspect is that this case shows that exploration is an activity that can coexist with existing land uses. It is here stressed that it is important with a work plan that shows a minimum impact from exploration on other land uses and relevant actors, and that this is communicated in a transparent way with all the affected parties.

To analyze this case using the concept of creating shared value, there are a number of issues that are relevant. The first issue is that this mine is suggested in an area where there already are a number of mining projects, and also a number of gold mines. This links to the third point of creating shared value, i.e., enabling local cluster development. Thus, the success of this company is likely related to the supporting companies and infrastructure around it. There is a "gold-mine" cluster in the Skelleftea area, which thus facilitates a shared value perspective in this case. The second issue relates to the second way to create shared value according to Porter and Kramer-redefining productivity in the value chain. Here it is noted that the case study stresses that the mining operations work plan is focused on a minimum necessary impact on other land uses and affected actors. This is vital for a shared value perspective, and this statement illustrates that this is understood by the mining operator. As well, it is noted in the case description that a weighted assessment of different land uses has been conducted. This illustrates that the authorities involved in this case have adopted a value approach-something noted as important for creating shared value in Porter and Kramer's framework. Lastly, it is stressed that a shared value perspective goes further than the legislation and ethical standards. In this case, the company have used consultants to perform a thorough analyses of how the reindeer herding will be affected in three Sami villages [43]. Thus, important stakeholders have been engaged at an early stage.

In sum, this case illustrates that a shared value perspective seems to have been present in the permitting process, linking all affected land uses to the consequences of the mining operation in a sound way. Furthermore, the mining operator stresses a minimum impact on surrounding nature. A citation from their webpage is "Botnia Exploration's objective is to become an international showcase for profitable small scale mining with limited environmental impact" [44]. However, this case relates to a relatively small under-ground operation that only plans to be active for $4-5$ years. Thus, larger projects often face considerably larger impacts which can be more difficult to address.

\subsubsection{Mining Project in the Boliden Area}

The second case involves the Boliden company, and addresses its tools to retain a Social License to Operate in the Boliden Area within the larger Skelleftea Area (see Figure 1). The company currently has three active underground mines and one open pit mine in the area, and is involved in all stages of mining in the area (from exploration, project development, active mining extraction, remediation and long-term use of land). The minerals mined are zinc, copper, lead, gold, silver and tellurium, and the scale of mining effects ranges from local to regional (as the operating mines are spread over the Skelleftea area) [42]. This case is directed towards the company's strategy of stakeholder interactions with affected land use interests in the area. The stakeholders comprised of, e.g., landowners, reindeer herders (a number of affected Sami villages), local community and hunters. The case is thus about good examples of how to communicate and coexist with other land use interests. 
In the Minland project, this case is noted as a "Good practice" case in relevance to integrating social aspects and civil society involvement [42]. The first aspect is related to an extensive and collaborative civic engagement process for a rehabilitation plan. Here it is noted that an independent landscape design agency was responsible for the planning of the rehabilitation plan, which ensured transparency, trust and an un-biased process. In this process a wide range of stakeholders were involved, and this participatory approach started early. The second aspect relates to establishing and managing relations with Sami villages that facilitate a Social License to Operate and the co-existence of land use. This aspect involved the re-establishment of reindeer grazing areas in the abovementioned rehabilitation plan. It also involved ICT and web applications to better monitor reindeer movement and therefore, reduce traffic accidents.

This case is highly relevant in a shared value perspective, not least as it addresses strategies for improving participatory community engagement in current mining operations [42]. The first key to create shared value, i.e., reconceiving products and markets, highlights the importance of adding shared value from the company's operations. The rehabilitation plan that this project establishes is a good example of creating shared value after the mining operations have been seized. A participatory process where the entire civil community is invited is a relevant approach in such a plan. The second key to create shared value according to Porter and Kramer, i.e., to redefine productivity in the value chain, stresses that a company's value chain affects a number of societal issues. It is these issues that this case tries to address and find sustainable solutions for. Another important aspect regarding a shared value perspective is in enabling local cluster development. As this area is also located in the larger Skellefteå area, which can be seen as a mining cluster in Northern Sweden, there are supporting industries and infrastructures that facilitate mining projects. Finally, this case develops an application for the phones to be used by drivers so that road accidents, where reindeers are affected, can be minimized.

To summarize, this case is an example of where a large mining company in Sweden, Boliden $\mathrm{AB}$, develops a strategy of stakeholder interactions with affected land use interests in the Boliden area. This case is thus an example of where a company, in some parts, adopts a shared value perspective. The development of an application that can better monitor reindeer movements in order to minimize the impact from road accidents is an example of a solution that moves beyond current legislation in order to improve economic and social benefits.

\subsubsection{Iron Ore Mining Project in Mertainen, Kiruna}

This third and last case in Sweden is related to an iron ore project which is part of LKAB's (the large state owned iron ore company in Sweden) mining operations in the Kiruna area in the northernmost parts of Sweden (see Figure 1). Mertainen is located close to Svappavara in Kiruna municipality, where LKAB already operates an existing mine and also a pelletizing plant [42]. However, there are no residential areas close to the planned mining site, which decreases direct disturbance to the local population and possibly less resistance to the mine. The mine project does, however, have an impact on reindeer herding and two Sami villages are directly affected. Furthermore, the mine project will also affect areas that are sensitive for the preservation of valuable nature. This case highlights competing land uses and especially solutions to negative impacts of mining operation on competing land uses, and successful stakeholder interactions.

In the Minland project, this case is noted as a "Good practice" case in relation to weighting different land uses and in the integration of social aspects and civil society involvement [42]. There are a number of aspects that are relevant for good practice conclusion. Regarding the first aspect, weighting different land uses, it is noted that different land uses were weighted according to all the pillars of sustainability as well as optimal use in the environmental permitting process. It is stressed that the impacts on all land uses were considered, and that the impacts from the mine on other land uses were minimized. The second aspect is related to compensation measures and regarding this it is 
noted that a new practice for compensating sensitive nature by setting aside other land areas have been established. The third aspect relates to interaction with stakeholders. It is noted that it is important to start stakeholder interactions as early as possible in the process, in order to prevent and handle potential land use conflicts. Furthermore, it is suggested to work in a preventive manner and not only to follow what is demanded in the regulations, but also to focus on stakeholder contacts, which builds trust and acceptance. The fourth aspect relates to the planning of the industrial and mining area. The importance of planning the industrial site is to minimize the impact on other land use interests, e.g., a sensitive nature, is stressed. It is also discussed that high competence in both the company and authorities regarding environmental impacts are necessary.

When analyzing this case in a shared value perspective according to Porter and Kramer, there are a few issues that seem important. The first is regarding the third aspect, where it is noted that the mining company has worked to be preventive with stakeholders, and also has had contacts that were outside what was demanded by the regulation. This is an important aspect in a shared value perspective according to Porter and Kramer. Another interesting issue is that regarding the aspect of weighting different land uses, it is apparent that a value approach has been adapted by both the involved authorities and the company. Furthermore, it is here also noted that it is important that the company's operations minimize the impact of other land uses. This is related to the key aspect of redefining productivity in the value chain according to Porter and Kramer. Regarding enabling the local cluster development, it is here noted that this operation is located within $12 \mathrm{~km}$ of LKABs and another mine and pelletizing plant in Svappavara. Thus, this project adds to the mining cluster that is already in place in this area. Finally, the aspect relating to a new compensation measure can also be seen as a shared value perspective, as it addresses the company's understanding that its operations have an impact on the civil society that needs to be handled in a societally accepted way.

In sum, this case illustrates a mining project handled by the large state-owned company LKAB. It shows, through a number of aspects, that a shared value perspective has been present in the establishment of the mining operation. One important aspect in this conclusion is that the firm has had contacts with stakeholders that are outside what is demanded by the current regulation, and also that they stress the importance of minimizing impacts on other land uses, as well as developing a compensation scheme where other land uses are compensated for the projects impacting on their interests.

\subsection{Norwegian Case}

There is one mining-related project in Norway that was identified as a "Good practice" in the Minland project [42]. This case deals with integration and valuation of mineral deposits in land use planning in the Nordland County. The focus here is to present aspects relevant for linking land use planning to mineral resources, and to analyze these in a shared value perspective according to Porter and Kramer.

\section{Mineral Resources and Land Use Planning in Nordland County}

This case presents a system of land use planning and the management of mineral resources in the Nordland County, located in the Northern parts of Norway. Nordland County is an important mining region in Norway, and at the same time it includes 8 national parks and reindeer herding is extensive in the area. The current extraction includes iron, calcite and dolomite marbles, quartz and construction raw materials. However, nickel, copper, zinc and lead have historically also been important commodities, and prospecting have found critical raw materials in the area [42]. The main purpose of this case is to classify mineral deposits in order to better predict and mediate potential land use conflicts related to future mineral extraction.

In the Minland project in this case is noted as a "Good practice" case in relation to data-assessment and use in land use planning, as well as the integration between policies related to minerals and land uses [42]. The first aspect that is seen as important for this case 
is that data regarding mineral resources have been improved and shared with all relevant land use planners, which ensures transparency and visibility of mineral resources on equal terms to other land uses. The second aspect which is lifted as important for seeing this case as a good practice is the integration of mineral resources in land use planning. Here it is suggested that mineral resources should be considered and thus included more formally in the Norwegian land use planning process. This is linked to the third aspect, which is to develop national and regional policies and strategies for managing mineral resources in land use planning. The goal is here to work to be preventive in order to reduce potential conflicts in land use planning cases.

When analyzing this case in a shared value perspective according to Porter and Kramer, it is a bit different considering that there is no company that is directly relevant in this case, but rather, the case describes a process that is more on a government and civil society level. However, the principles can still be applied, as a shared value perspective cuts across a traditional divide between responsibilities of business and those of governments. A shared value perspective is to find ways to boost productivity in a specific area. Here it is noted by the authors that governments and policies should focus on introducing standards and support for technology that promote innovation, improves the environment and increases competitiveness at the same time [11]. When relating this to the good practice aspects in the Nordland County case, it is noted that providing better data regarding where important mineral deposits are located to relevant actors responsible for land use planning is thus an action that can foster the creation of shared values in future mining operations. Moreover, to integrate mineral resources in land use planning legislation, and create policies and strategies for this integration, can, in a shared value perspective, be seen as a regulation that enhances shared values and can stimulate innovation, as it can encourage companies in future investments.

In sum, this case focuses on governmental regulation and strategies to incorporate mineral resources in land use planning in Norway. It also develops strategies for making data on mineral resources available for all in order to avoid future land use conflicts. This is an example of how government and civil society can act in a shared value perspective and thus facilitate for a transparent and clear system that can be used in future mining operations.

\subsection{Finnish Case}

There is one mining project in Finland that were identified as a "Good practice" case in [42]. This case is the Kevista mine owned by the Swedish company Boliden and is located in Lapland in the Northern parts of Finland (see Figure 1). The area where the mine is located has many competing land uses and the case thus deals with integration of land use planning, environmental commitment and a Social License to Operate.

\section{Kevitsa Mine Located in the Lapland Region}

This case involves the Boliden company, and addresses how mining activity is possible in an area with many competing land uses, e.g., valuable nature and tourism. It further provides a good example of how to include mineral exploitation aspects in land use planning at different levels. The minerals mined in Kevitsa are primarily nickel and copper, but also gold, platinum and palladium are found in this open-pit mine. In 2020 about 9186 ktonnes of ore were processed into concentrates, and the average number of employees was 560 [45]. The mine is located in the Sodänkylä municipality. The mine has developed slowly since its discovery in 1987 and acceptance for the mining operation by the community has increased over time [42]. The municipality also stress the social and economic sustainability that the mine brings, e.g., employment, housing needs, increase in service needs and so on.

In the Minland project, this case is noted as a "Good practice" case in relation to integration of land use planning, environmental commitment and social aspects [42]. The first aspect for this conclusion is that this case shows an effective environmental and societal performance. This is due to an early communication between a diverse set of stakeholders 
(which is demanded by the regulation). It is further stressed that guidelines have been created that support exploration activities in protected areas. Regarding environmental performance, it is noted that requirements for lower emissions, and especially that the company fulfills these requirements, improves environmental performance, which builds trust for other involved stakeholders. The second aspect is to include mineral resources in land use planning. Here it is suggested that the land use planning process should allow a re-evaluation of land use over time, to consider new development possibilities. It is further stressed that socio-economic factors change over time, and should therefore be considered continuously given new demands and interests.

In a shared value perspective [11], there are a number of issues of this case that are relevant. One of these regards the first aspect above, where it is noted that environmental performance is important for building trust with stakeholders. This is linked to Porter and Kramer's key point to redefine productivity in the value chain, as the success of the company in this case was reliant on their willingness to comply and increase the environmental performance of the mine. Thus, the externalities that the mine inflicted on the surrounding environment needed to be internalized (at least to some extent) in order to get acceptance. The second issue that can be seen in a shared value perspective, is that a value approach is stressed in the second aspect. It is an issue more directed towards authorities, as it deals with linking land use planning to mineral resources, but mostly it is about a constant valuation of socioeconomic effects that arises from different land uses.

To summarize the conclusions from this case, it is evident that a shared value perspective has been present in the two aspects that are discussed in the case study prepared in the Minland project. However, in this case it was stated that the company followed the regulation and normal procedures for the environmental standards. In a shared value perspective, it is stressed that moving beyond what is required in the regulation is often necessary for successful implementation. Considering this, the firm could possibly have acted in a more pro-active way with a focus on minimizing environmental impact that goes beyond what is required by regulation.

\section{Discussion}

The results presented in the cases above indicate that a shared value perspective has been present in all the "Good practice" cases that have been scrutinized in this paper, at least to some extent. Obviously, this has not been the focus of the cases; however, it is interesting to note that the aspects that form the conclusion for "Good practice", in many ways are similar to what Porter and Kramer lift as key points for creating shared value. This indicates that if the involved actors in mining projects recognize that economic and social value are linked to each other, and that it is sometimes necessary to have a societal perspective that can go beyond what is required by the current regulation, it is more likely that the project will be successful. In other words, all societal effects (both positive and negative externalities) from mining projects need to be internalized in order to successfully implement these projects.

A shared value perspective is easier to detect in the cases where a responsible company is present in the project. Thus, in the case where only an authority level is applied (the Norwegian case), it is less obvious that a shared value perspective has been present. However, according to [11], the principles of shared value apply equally to responsible authorities. It is stressed that authorities should think in value terms, and focus on environmental performance and standards that use technological solutions that promote innovation and improve the environment at the same time. In the analyses above, this perspective is to some extent missing or at least not obvious in all the cases scrutinized. A conclusion is therefore that involved authorities, on all levels, most likely can take a more active role in creating a shared value for societal progress that fosters both social value and economic value. Furthermore, it is often local and regional authorities that are responsible for the land use planning, which implies that they need to take a holistic approach in mining project dialogues in order to have an efficient land use planning process. 
Regarding the concept of creating shared value, it is not (at least to the author's knowledge) directly targeted in previous literature discussing the issue of mineral safeguarding and land use planning. However, the concept of creating shared values are to some extent present in a number of previous studies. For example, Wilson addresses the concept of Benefit Sharing, which in many ways is related to creating shared value as it implies that the extractive industries to a larger extent need to share the benefits of resource developments to those affected by the extraction [14]. Furthermore, in [13], socioeconomic value creation and the role of local participation in mining projects in the Arctic is addressed. Here, local socioeconomic value creation is achieved through direct employment, training and integration of supporting industries, as well as taxes and royalties. This is highly relevant for creating shared value, i.e., direct employment and training is a way for companies to create social value to the local population. Moreover, integration of supporting industries is similar to Porter and Kramer's discussion of enabling local cluster development. Thus, creating shared value has been present in many of the solutions regarding access to mineral resources and land use conflicts in the previous literature.

It should though be noted that the cases analyzed in this paper have all been so called "Good practice" cases, and thus have been successful in linking land use planning and mineral safeguarding. It is likely that an analysis of cases that have not been successful in this regard would not have detected the principles of a shared value perspective as easily. It would therefore be of interest to also analyze cases that have failed with regard to these aspects, in order to see if a shared value perspective was lacking and thus if this such a perspective would have helped the implementation of these mining projects. Moreover, even if the principles of creating shared value has been detected in the case studies scrutinized in this article, there is room for improvement. If companies and involved authorities focus more on creating shared value from a societal perspective, it is likely that some of the opposition that mining projects meet can be resolved. In the Nordic countries analyzed in this paper, it is clearly the case that mining firms and local authorities that see mining projects as possibilities from a regional economic perspective need to focus on how these projects also can create value for the affected Sami villages. A closer collaboration with involved Samis (and other local residents that oppose mining projects) is therefore crucial to also take into account their perspective.

\section{Conclusions}

The main aim of this paper has been to investigate the link between mineral deposit safeguarding and land use planning, when using a shared value perspective. The analysis has focused on five mining projects in the Nordic countries (Sweden, Norway and Finland) that were defined as "Good practice" cases, in the EU project Minland, related to linking land use planning and mineral safeguarding issues. All of these cases have thus been seen as successful in this regard, but this paper has added a shared value perspective to the analysis.

The results of the paper show that a shared value perspective has been present in the analyzed cases when studying the three key ways of creating shared value according to Porter and Kramer, i.e., reconceiving products and markets, defining productivity in the value chain and enabling local cluster development. An important aspect for creating shared value in practice is to comply with the law and with ethical standards, but it goes beyond that. Thus, companies should focus on what is best from a societal perspective and apply a shared value lens to all major decisions. This is required for social acceptance and also for generating both economic and social value, as social harm will imply costs for the companies.

To conclude, as mining projects involve the extraction of natural resources and often in areas with many competing land uses, it is understandable that if the mining project fails to internalize all social, environmental and economic effects, the operation will not be sustainable and therefore will be contested by other stakeholders. Considering this, it is crucial that involved actors apply the principles of creating shared value in future 
mining projects. Regarding the issue of achieving an efficient mineral deposit safeguarding that is linked to land use planning, dialogue and collaboration between all involved stakeholders is a key aspect according to all analyzed cases. It is also noted that it is important that the dialogues start early, and that they are conducted in a way so that it is an open environment where all the different stakeholder's perspectives and values can be expressed and respected.

The findings in this paper stress the importance of a shared value perspective, as well as dialogue and collaboration with different stakeholders, in order to achieve social value, which in turn will lead to economic value. As it is many times the unpredictability of the regulatory framework that hinders investments, it is suggested that a so-called Social Impact Assessment is added to the current legislation. This is to ensure that the principles of creating shared value is more visible in current procedures.

Funding: This article has been supported by the Polish National Agency for Academic Exchange under Grant No PPI/APM/2019/1/00079/U/001.

Institutional Review Board Statement: Not applicable.

Informed Consent Statement: Not applicable.

Data Availability Statement: Not applicable.

Acknowledgments: I am very grateful to the three anonymous reviewers for their constructive comments on the first submission of this paper.

Conflicts of Interest: The author declares no conflict of interest.

\section{References}

1. European Commission. Horizon 2020 Programme Raw Materials. 2020. Available online: https://ec.europa.eu/programmes/ horizon2020/en/area/raw-materials (accessed on 22 December 2020).

2. European Commission. Action Plan on Critical Raw Materials. 2020. Available online: https://ec.europa.eu/docsroom/ documents / 42849 (accessed on 6 April 2021).

3. Arrobas, D.; Hund, K.; McCormick, M.; Ningthoujam, J.; Drexhage, J. The Growing Role of Minerals and Metals for a Low Carbon Future; World Bank Group: Washington, DC, USA, 2017.

4. Ali, S.; Giurco, D.; Arndt, N.; Nickless, E.; Brown, G.; Demetriades, A.; Durrheim, R.; Eriquez, M.A.; Kinnard, J.; Littleboy, A.; et al. Mineral supply for sustainable development requires resource governance. Nature 2017, 543, 367-372. [CrossRef] [PubMed]

5. Tiess, G. Minerals policy in Europe: Some recent developments. Resour. Policy 2010, 35, 190-198. [CrossRef]

6. Wrighton, C.E.; Bee, E.J.; Mankelow, J.M. The development and implementation of mineral safeguarding policies at national and local levels in the United Kingdom. Resour. Policy 2014, 41, 160-170. [CrossRef]

7. Gugerell, K.; Endl, A.; Gottenhuber, S.L.; Ammerer, G.; Berger, G.; Tost, M. Regional implementation of a novel policy approach: The role of minerals safeguarding in land-use planning policy in Austria. Extr. Ind. Soc. 2020, 7, 87-96. [CrossRef]

8. Gałaś, S. Assessment of implementation of protection of mineral deposits in spatial planning in Poland. Land Use Policy 2017, 67, 584-596. [CrossRef]

9. Minland Project. Mineral Resources in Sustainable Land-Use Planning. Available online: https://www.minland.eu/ (accessed on 22 December 2020).

10. The Swedish Agency for Economic and Regional Growth. Handbok för Kommuner som Star Inför Gruv- Eller Täktsatsningar (Only Available in Swedish). 2020. Available online: https://tillvaxtverket.se/vara-tjanster/publikationer/publikationer-2020/2 020-09-22-handbok-for-kommuner-som-star-infor-gruv--eller-taktsatsningar.html (accessed on 21 December 2020).

11. Porter, M.; Kramer, M. Creating shared value. How to re-invent capitalism-And unleash a wave of innovation and growth. Harv. Bus. Rev. 2011, 89, 62-77.

12. Beland Lindahl, B.; Johansson, A.; Zachrisson, A.; Viklund, R. Competing pathways to sustainability? Exploring conflicts over mine establishments in the Swedish mountain region. J. Environ. Manag. 2018, 218, 402-415. [CrossRef] [PubMed]

13. Kadenic, M. Socioeconomic value creation and the role of local participation in large-scale mining projects in the Arctic. Extr. Ind. Soc. 2015, 2, 562-571. [CrossRef]

14. Wilson, E. What is benefit sharing? Respecting indigenous rights and addressing inequities in arctic resource projects. Resources 2019, 8, 74. [CrossRef]

15. Wilson, E.; Stammler, F. Beyond extractivism and alternative cosmologies: Arctic communities and extractive industries in uncertain times. Extr. Ind. Soc. 2016, 3, 1-8. [CrossRef]

16. Xing, M.; Awuah-Offei, K.; Long, S.; Usman, S. The effect of local supply chain on regional economic impacts of mining. Extr. Ind. Soc. 2017, 4, 622-629. [CrossRef] 
17. Deller, S. Does mining influence rural economic growth? J. Reg. Anal. Policy 2014, 44, 36-48.

18. Mateus, A.; Lopes, C.; Martins, L.; Carvalho, J. Towards a multi-dimensional methodology supporting a safeguarding decision on the future access to mineral resources. Miner. Econ. 2017, 30, 229-255. [CrossRef]

19. The Geological Survey of Sweden. Statistics of the Swedish Mining Industry 2019; The Geological Survey of Sweden: Uppsala, Sweden, 2020.

20. Government Offices of Sweden. Sweden's Mineral Strategy_For Sustainable Use of Sweden's Mineral Resources That Creates Growth throughout the Country; Swedish Ministry of Enterprise, Energy and Communications: Stockholm, Sweden, 2013.

21. Haikola, S.; Anshelm, J. Mineral policy at a crossroads? Critical reflections on the challenges with expanding Sweden's mining sector. Extr. Ind. Soc. 2016, 3, 508-516. [CrossRef]

22. Fraser Institute. Annual Survey of Mining Companies; Fraser Institute: Vancouver, BC, Canada, 2020. Available online: https: / / www.fraserinstitute.org/studies/annual-survey-of-mining-companies-2020 (accessed on 26 February 2021).

23. Government Offices of Sweden. Minerals Act (1991:45). Available online: https:/ / www.government.se/ (accessed on 26 February 2021).

24. Government Offices of Sweden. Environmental Code (1998:808). Available online: https:/ /www.government.se/ (accessed on 26 February 2021).

25. Government Offices of Sweden. Planning and Building Act (2010:900). Available online: https://www.government.se/ (accessed on 26 February 2021).

26. Government Offices of Norway. Strategy for the Mineral Industry; Ministry of Trade and Industry: Oslo, Norway, 2013.

27. Government Offices of Norway. Minerals Act (2009:101). Available online: https://www.government.se/ (accessed on 26 February 2021).

28. Hojem, P. Mining in the Nordic Countries: A Comparative Review of Legislation and Taxation; Nordisk Ministerråd: Copenhagen, Denmark, 2015.

29. Government Offices of Norway. Planning and Building Act (2008:71). Available online: https://www.government.se/ (accessed on 26 February 2021).

30. The Geological Survey of Finland. Finland's Mineral Strategy; The Ministry of Employment and the Economy: Helsinki, Finland, 2010.

31. Government Offices of Finland. Mining Act (621/2011). Available online: https:/ / www.government.se/ (accessed on 26 February 2021).

32. Rølmer, S. Is Sweden Becoming a High-Risk Jurisdiction for Exploration and Mining? 2018. Available online: https:/ /www.linkedin. $\mathrm{com} /$ pulse/sweden-becoming-high-risk-jurisdiction-exploration-mining-r\%C3\%B8lmer (accessed on 28 December 2020).

33. Svemin. More Efficient Permit Processes under Way. 2020. Available online: https://www.svemin.se/en/news/news/moreefficient-permit-processes-underway/ (accessed on 28 December 2020).

34. Arctic Today. UN Criticizes Sweden for Failing to Consult Sámi on Mining Permit. 2020. Available online: https://www. arctictoday.com/un-criticizes-sweden-for-failing-to-consult-sami-on-mining-permit/ (accessed on 28 December 2020).

35. Raitio, K.; Allard, C.; Lawrence, R. Mineral extraction in Swedish Sápmi: The regulatory gap between Sami rights and Sweden's mining permitting practices. Land Use Policy 2020, 99, 1-15. [CrossRef]

36. Söderholm, K.; Söderholm, P.; Helenius, H.; Pettersson, M.; Viklund, R.; Masloboev, V.; Mingaleva, T.; Petrov, V. Environmental regulation and competitiveness in the mining industry: Permitting processes with special focus on Finland, Sweden and Russia. Resour. Policy 2015, 43, 130-142. [CrossRef]

37. Pigou, A. Welfare and Economic Welfare. In The Economics of Welfare; Palgrave Macmillan: London, UK, 1920; pp. 3-22.

38. The Economist. Oh, Mr Porter. The Economist. 2011. Available online: https://www.economist.com/weeklyedition/2011-03-12 (accessed on 22 February 2021).

39. Crane, A.; Palazzo, G.; Spence, L.; Matten, D. Contesting the value of the shared value concept. Calif. Manag. Rev. 2014, 56, 130-153. [CrossRef]

40. Hartman, L.; Werhane, P. Proposition: Shared value as an incomplete mental model. Bus. Ethics J. Rev. 2013, 1, 36-43. [CrossRef]

41. Beschorner, T.; Hajduk, T. Creating shared value: A fundamental critique. Z. Wirtsch. Unternehmensethik. 2015, 16, 219-230. [CrossRef]

42. Minland. Good Practice Guidelines. D6.2: Final Manual for Good Practice Guidance. Available online: https://www.minland. eu/project-results / good-practice-guidelines / (accessed on 22 February 2021).

43. Tyréns. Bilaga C5 Rennäringsanalyser (Only Available in Swedish). Available online: http://www.botniaexploration.com/ wordpress/wp-content/uploads/2018/11/Bilaga-C.5-Renna\%CC\%88ringsanalyser.pdf (accessed on 22 February 2021).

44. Botnia Exploration. Available online: https://www.botniaexploration.com/ (accessed on 22 February 2021).

45. Boliden. Available online: https://www.boliden.com/operations/mines/boliden-kevitsa (accessed on 6 April 2021). 